\title{
The Hedgehog System Machinery Controls Transforming Growth Factor- $\beta$-Dependent Myofibroblastic Differentiation in Humans
}

\author{
Involvement in Idiopathic Pulmonary Fibrosis
}

\author{
Natacha Cigna, ${ }^{*}$ Elika Farrokhi Moshai, ${ }^{*}$ \\ Stéphanie Brayer, ${ }^{*}$ Joëlle Marchal-Somme, ${ }^{*}$ \\ Lidwine Wémeau-Stervinou, ${ }^{*}$ Aurélie Fabre, ${ }^{* \dagger}$ \\ Hervé Mal, ${ }^{* \ddagger}$ Guy Lesèche, ${ }^{\star \S}$ Monique Dehoux, ${ }^{* \Uparrow}$ \\ Paul Soler, ${ }^{*}$ Bruno Crestani, ${ }^{* \|}$ and \\ Arnaud A. Mailleux ${ }^{*}$ \\ From INSERM U7OO,* Paris Diderot University, Paris; and the \\ Departments of Anatomic Pathology, ${ }^{\dagger}$ Pneumology and \\ Transplantation, ${ }^{*}$ Thoraicic Surgery, Biochemistry, ${ }^{\text {Tा }}$ and \\ Pneumology," Public Assistance-Paris Hospital (APHP), Bichat \\ Hospital, Paris, France
}

Idiopathic pulmonary fibrosis (IPF) is a devastating disease of unknown cause. Key signaling developmental pathways are aberrantly expressed in IPF. The hedgehog pathway plays a key role during fetal lung development and may be involved in lung fibrogenesis. We determined the expression pattern of several Sonic hedgehog (SHH) pathway members in normal and IPF human lung biopsies and primary fibroblasts. The effect of hedgehog pathway inhibition was assayed by lung fibroblast proliferation and differentiation with and without transforming growth factor (TGF)- $\beta 1$. We showed that the hedgehog pathway was reactivated in the IPF lung. Importantly, we deciphered the cross talk between the hedgehog and TGF- $\beta$ pathway in human lung fibroblasts. TGF- $\beta 1$ modulated the expression of key components of the hedgehog pathway independent of Smoothened, the obligatory signal transducer of the pathway. Smoothened was required for TGF- $\beta 1$-induced myofibroblastic differentiation of control fibroblasts, but differentiation of IPF fibroblasts was partially resistant to Smoothened inhibition. Furthermore, functional hedgehog pathway machinery from the primary cilium, as well as GLI-dependent transcription in the nucleus, was required for the TGF- $\beta 1$ effects on normal and IPF fibroblasts during myofibroblastic differentiation. These data identify the GLI tran- scription factors as potential therapeutic targets in lung fibrosis. (Am J Pathol 2012, 181:2126-2137; http://dx.doi. org/10.1016/j.ajpath.2012.08.019)

Idiopathic pulmonary fibrosis (IPF) is a devastating disease of unknown cause that is associated with accumulation of extracellular matrix (ECM) and fibroblasts in the distal airways. The resulting disorganization and destruction of alveoli lead to irreversible disturbance of mechanical properties and lack of gas exchange function. ${ }^{1}$ The pathophysiologic mechanisms of IPF are poorly known. IPF was hypothesized to result from repeated injury to the alveolar epithelium from an unknown trigger, concomitant with improper tissue repair, ${ }^{1}$ aberrant epithelium-fibroblast interactions ${ }^{2}$ with the reactivation of processes involved during lung development. ${ }^{3}$

Among the embryonic developmental signaling pathways, the hedgehog $(\mathrm{HH})$ pathway plays a critical role in lung ontogenesis because it is involved in epithelialmesenchyme interactions. Sonic hedgehog $(\mathrm{SHH})$, desert hedgehog $(\mathrm{DHH})$, and Indian hedgehog $(\mathrm{IHH})$ are secreted factors and the 3 mammal orthologs of Drosophila $\mathrm{HH}$ protein. ${ }^{4}$ The role of $\mathrm{SHH}$ in mouse lung develop-

Supported by the European Commission (FP7 project no. 202224, European Idiopathic Pulmonary Fibrosis Network), the French National Research Agency (ANR Physio 2006, FIBROPNEUMO), the Chancellery of Paris Universities (Poix Legacy), the Mariane Josso award (S.B.), the French Medical Research Foundation (L.W.-S.), a grant from LVL Medical (E.F.), the Respiratory Health Research endowment fund (E.F.)., and an INSERM/APHP interface contract (P.S.). This work was conducted within the FIRE University Hospital Department (DHU).

Accepted for publication August 8, 2012

B.C. and A.A.M. share senior authorship.

Supplemental material for this article can be found at http://ajp. amjpathol.org or at $h$ ttp://dx.doi.org/10.1016/j.ajpath.2012.08.019.

Address reprint requests to Arnaud A. Mailleux, Ph.D., INSERM U700, 16 rue Henri Huchard 75018, Paris, France. E-mail: arnaud.mailleux@ inserm.fr. 
ment has been well documented. Shh signaling controls the growth and survival of the embryonic lung mesenchyme and is also required for proper lung branching morphogenesis. ${ }^{5} \mathrm{HH}$ signal transduction is mediated by 2 transmembrane proteins: Smoothened (SMO), the obligatory signal transducer; and the $\mathrm{HH}$-binding receptor Patched-1 (PTC), which constitutively blocks SMO activity in the absence of SHH. SHH binding to PTC unleashes SMO activity and activates the downstream cascade by allowing for biochemical processing of the zinc-finger transcription-factor GLI family (GLI1, GLI2, and GLI3). ${ }^{4}$ In addition, $\mathrm{HH}$ interacting protein 1 (HHIP), a transmembrane decoy receptor, can sequester the ligand $\mathrm{SHH}$ to inhibit the pathway. ${ }^{6}$ A model of canonical $\mathrm{HH}$ pathway is shown in Supplemental Figure S1 (available at $h$ ttp://ajp.amjpathol.org).

At the cellular level, recent studies have shown that several components of the $\mathrm{HH}$ signaling pathway were localized at the primary cilium. ${ }^{4}$ This nonmotile organelle is required for coupling SMO activity to the GLI downstream transduction pathway. The activation of GLI is also regulated independently from the primary cilium by Suppressor of Fused/speckle-type POZ (SUFU/SPOP) antagonist proteins. SUFU interacts and protects fulllength GLI2 and GLI3 against SPOP-mediated proteasome degradation ${ }^{7}$ and may regulate GLI nuclear/cytoplasmic distribution in the cell. ${ }^{4}$

The expression of several components of the $\mathrm{HH}$ pathway (eg, SHH, PTC, and GLI1) was previously reported in remodeling type II alveolar epithelial cells in $\mathrm{IPF}^{8,9}$ and during experimental lung fibrogenesis. ${ }^{10}$ However, the role of the pathway in adult lung homeostasis and in the repair process is still poorly understood. In the light of the crucial role of $\mathrm{HH}$ signaling during lung development and diseases, perturbations of the expression pattern and/or the downstream signaling pathways may contribute to lung fibrogenesis.

In this study, (1) we dissected the expression pattern of key $\mathrm{HH}$ signaling components in lung samples from control subjects and patients with IPF, (2) evaluated the phenotypic consequences of inhibiting the $\mathrm{HH}$ pathway in control and IPF human lung fibroblasts (HLFs), and (3) deciphered the cross talk between the $\mathrm{HH}$ and transforming growth factor (TGF)- $\beta$ signaling pathways in control and IPF HLFs during myofibroblastic differentiation.

\section{Materials and Methods}

\section{Human Lung Biopsy and Bronchoalveolar Lavage}

IPF lung samples were obtained from patients undergoing open lung biopsy ( $n=8$; seven men). IPF was diagnosed according to American Thoracic Society-European Respiratory Society consensus criteria, ${ }^{11}$ including characteristic features of usual interstitial pneumonia. The median age of patients was 60 years (range, 51 to 65 years). Four were exsmokers and three were lifetime nonsmokers. The median time to biopsy after the beginning of symptoms was 10.5 months (range, 2 to 189 months).
At the time of lung biopsy, all patients received oral prednisone with $\mathrm{N}$-acetylcycsteine for one patient and azathioprine for two patients. Control lung samples were obtained from a noninvolved segment of 8 patients (4 men) who were undergoing lung surgery for removal of a primary lung tumor. The median age was 59 years (range, 34 to 80 years). Two patients were lifetime nonsmokers, three were exsmokers, and three were active smokers. Written informed consent was obtained from all subjects. Bronchoalveolar lavage fluid (BALF) was obtained as part of the diagnostic workup, as previously described, ${ }^{12}$ from control patients $(n=13)$, stable patients with IPF $(n=35)$, and patients with IPF with acute exacerbation $(n=7)$. Exacerbation was defined according to Collard et al. ${ }^{13}$

\section{Cell Culture}

Primary fibroblasts from seven patients with IPF and seven controls were derived from human lung explants as previously described. ${ }^{2}$ Primary HLFs were cultured in Dulbecco's modified Eagle's medium (Gibco, Grand Island, NY) supplemented with $10 \%$ fetal calf serum and antibiotics as previously described ${ }^{2}$ and used at passage 5 . HLFs were treated (30 minutes to 72 hours) with human recombinant TGF- $\beta 1$ ( $1 \mathrm{ng} / \mathrm{mL}$ ), cyclopamine (CYC; $5 \mu \mathrm{mol} / \mathrm{L}), 2,4-d i-$ chloro-a-(3,4-dihydro-4-oxo-2(1H)-quinazolinylidene)- $\beta$-oxobenzenepropanenitrile [hedgehog pathway inhibitor (HPI)-4; $20 \mu \mathrm{mol} / \mathrm{L}]$, cycloheximide (CHX; $20 \mu \mathrm{g} / \mathrm{mL})$ (Sigma-Aldrich, Saint Quentin Fallavier, France), 2,2'[[dihydro-2-(4-pyridinyl)-1,3(2H,4H)-pyrimidinediyl]bis(methylene)]bis[N,N-dimethylbenzenamine] (GANT61; 5 $\mu \mathrm{mol} / \mathrm{L}$ ) (Merck Millipore, Billerica, MA), or vehicle [ethanol for CYC or dimethyl sulfoxide (DMSO) for $\mathrm{CHX}$, GANT61, and HPI-4]. The dose-response effects and kinetics for CYC, HPI-4, and GANT61 were determined in preliminary experiments with CCL-210 primary normal HLFs (LGC Standards, Molsheim, France) with growth rate inhibition in the absence of cytotoxic effect as readout. Cytotoxic effects were assayed by trypan blue staining and observation of cells with structural features of apoptosis. Cytotoxic effects were observed at $10 \mu \mathrm{mol} / \mathrm{L}$ with $\mathrm{CYC}, 30 \mu \mathrm{mol} / \mathrm{L}$ with $\mathrm{HPI}-4$, and $10 \mu \mathrm{mol} / \mathrm{L}$ with GANT61.

For immunoblot and mRNA experiments, primary HLFs were plated in 6-well plates for 24 hours then starved in $0 \%$ fetal calf serum growth medium for 16 hours before stimulation. For immunofluorescence, HLFs were cultured on Permanox Lab-Tek Chamber Slides (Nunc, Thermo Fisher Scientific, Rochester, NY) as described. ${ }^{14}$ For rescue experiments, serum-starved fibroblasts were stimulated with TGF- $\beta 1$ for 48 hours before treatment. Differentiated myofibroblasts were then treated with $\mathrm{HH}$ pathway inhibitors or corresponding vehicle for 48 or 72 hours. For growth assay, HLFs were treated for 48 hours in medium containing $10 \%$ fetal calf serum with $\mathrm{HH}$ inhibitors or corresponding vehicle. Proliferation rate was measured by cell counting and cell viability with the use of a V-Cell counter (Beckman Coulter, Villepinte, France). 


\section{mRNA Analysis}

Total mRNA from human lung samples was extracted with the use of the Trizol Plus RNA Purification kit (Invitrogen, Saint-Quentin Fallavier, France), and cDNA was obtained from $2 \mu \mathrm{g}$ of total RNA with the use of Moloney Murine Leukemia Virus Reverse Transcriptase (Invitrogen, Carlsbad, CA). mRNA from fibroblasts was extracted with the use of the NucleoSpin RNA II kit (Macherey-Nagel GmbH \& Co., Düren, Germany). Reverse transcription involved $1 \mu \mathrm{g}$ of total RNA. The transcripts of ubiquitin $\mathrm{C}$ (UBC) were an endogenous RNA control. ${ }^{14}$ The expression of SHH, PTC, SMO, SUFU, SPOP, HHIP, GLI-1/2/3, $\alpha S M A, \alpha 2 C O L-1, F N 1$, and UBC mRNA was quantified by real-time PCR (see Table 1 for primers) with the use of PCR ABI 7500 (Applied Biosystems, Carlsbad, CA).

\section{Immunohistochemistry and Immunofluorescence}

For immunohistochemistry, paraffin-embedded tissue sections were treated as described. ${ }^{12}$ Primary antibodies for immunohistochemistry were anti-SHH (Cell Signaling Technologies, Danvers, MA; clone C9C5, no. 2207), antiPTC (Sc-6149); anti-SMO (both Santa Cruz Biotechnology, Santa Cruz, CA; Sc-13943), anti-GLI1 (AF3455), anti-GLI3 (both R\&D Systems, Minneapolis, MN; AF3690), anti-GLI2 (Abcam Inc., Cambridge, MA; Ab26056), anticyclin D1 (2261-1), and anti-BCL-2 (both Epitomics, Burlingame, CA; 1017-1). For immunofluorescence, paraformaldehyde-fixed HLFs were stained as described. ${ }^{15}$ Primary antibodies for immunofluorescence were anti- $\alpha$ smooth muscle actin ( $\alpha$-SMA; Sigma-Aldrich; clone 1A4; no. A2547), SMAD3 (Cell Signaling Technologies; clone C67H9; no. 9523), Pericentrin (Abcam Inc.; ab4448), acetylated-tubulin (Sigma-Aldrich; clone 6-11B-1; no. T7451), and phalloidin-coupled Alexa568 dye (Invitrogen). To test the specificity of immunostaining, antibodies were omitted or replaced by an isotype-matched control antibody. Digital images were acquired under a DM400B light microscope (Leica, Wetzlar, Germany) equipped with a Leica DFC420 CDD camera. Digital images for immunofluorescence were acquired under an IX70 fluorescence microscope (Olympus, Tokyo, Japan) equipped with an X-cite $Q$ source (Olympus) and an ORCA-03G CCD camera (Hamamatsu Corp., Bridgewater, NJ) with Cell-A software version 3.3 (Olympus).

\section{Protein Analysis}

Primary fibroblasts in culture were lysed on ice in RIPA buffer $(10 \mathrm{mmol} / \mathrm{L}$ Tris- $\mathrm{HCl} \mathrm{pH} \mathrm{8,50} \mathrm{mmol/L} \mathrm{NaCl,} \mathrm{0.5 \%}$ Na deoxycholate, $0.2 \%$ SDS, $1 \%$ NP-40) supplemented with protease inhibitor cocktail inhibitor $(10 \mu \mathrm{g} / \mathrm{mL}$ aprotinin, $10 \mu \mathrm{g} / \mathrm{mL}$ leupeptin, $8.3 \mu \mathrm{g} / \mathrm{mL}$ pepstatin $A$, $2 \mathrm{mmol} / \mathrm{L}$ phenylmethylsulfonyl fluoride), then lysates were clarified by centrifugation $(13,000 \times g$ for 20 minutes at $4^{\circ} \mathrm{C}$ ). Samples of 10 to $30 \mu \mathrm{g}$ protein were examined by Western blot analysis. ${ }^{16}$ Primary antibodies were anti- $\alpha$-SMA (Sigma-Aldrich; clone 1A4; no. A2547), anti-collagen I (Southern Biotechnology Associates, Birmingham, AL; no. 1310-01), anti-fibronectin-1 (Abcam; ab23750), GAPDH (Abcam; ab9485), SMAD3 (clone C67H9; no. 9523), phospho-Smad3 (Ser423/425) (both Cell Signaling Technologies; clone C25A9; no. 9520), and $\gamma$-tubulin (Abcam; ab11317). Concentration of $\mathrm{SHH}$ protein in BALF $(100 \mu \mathrm{L})$ was assayed by enzyme-linked immunosorbent assay (ELISA) according to the RayBiotech instructions (Norcross, GA; ELH-ShhN-001). The detection threshold for the assay was $14 \mathrm{pg} / \mathrm{mL}$.

\section{Statistical Analysis}

Data are expressed as median (range) or mean \pm SEM. Statistical analysis involved the use of Prism version 5 (GraphPad Software, Inc., La Jolla, CA). Differences between IPF and control samples were determined by a $U$-test. The effects of agents and baseline conditions were compared by Wilcoxon paired nonparametric test. $P<0.05$ was considered statistically significant.

Table 1. Primer Sequences for Quantitative PCR

\begin{tabular}{|c|c|c|}
\hline \multirow[b]{2}{*}{ Gene } & \multicolumn{2}{|c|}{ Primer sequences } \\
\hline & Forward & Reverse \\
\hline $\mathrm{SHH}$ & $5^{\prime}$-GAAAGCAGAGAACTCGGTGG-3' & 5'-CTCAGGTCCTTCACCAGCTT-3' \\
\hline $\mathrm{IHH}$ & $5^{\prime}$-TCAGCCTGCTCTCACTACGA-3' & 5'-CAAAGGGGCCTAAGATGGAT-3' \\
\hline $\mathrm{DHH}$ & 5'-GACCGCAACAAGTATGGGTT-3' & 5' - TATCAGCTTTGACCGACACG-3' \\
\hline PTC & 5'-TGGCATAGGAGTGGAGTTCA-3' & 5' -ATCAGCACTCCCAGCAGAGT-3' \\
\hline HHIP & 5'-CATGTCGTCATGGAGGTGTC-3' & 5'-GCGGATGTTTCTGTCCACTT-3' \\
\hline SMO & 5'-CAGCAAGATCAACGAGACCA-3' & 5'-GGCAGCTGAAGGTAATGAGC-3' \\
\hline$G L / 1$ & 5'-CCAGCCAGAGAGACCAACA-3' & 5'-ATCCGACAGAGGTGAGATGG-3' \\
\hline GLI2 & 5'-TTTATGGGCATCСTCTCTGG-3' & 5' -AAGGCTGGAAAGCACTGTGT-3' \\
\hline GL/3 & 5'-ССТСССААСТССТСАСАСАТ-3' & 5'-CAACACCAACTGGTCCCTCT-3' \\
\hline SUFU & $5^{\prime}-\mathrm{ACATGCTGCTGACAGAGGAC}-3^{\prime}$ & $5^{\prime}$-CAGACACCAACGATCTGGAG-3' \\
\hline SPOP & $5^{\prime}$-TTCTGCGAGGTGAGTGTTGT-3' & $5^{\prime}$-GGCACTCAGGAACCTTTACC-3' \\
\hline UBC & 5'-CACTTGGTCCTGCGCTTGA-3' & 5'-TTTTTTGGGAATGCAACAACTT-3' \\
\hline$\alpha S M A$ & $5^{\prime}$-GAAGAGCATCCCACCCTGC-3' & 5'-ATTTTCTCCCGGTTGGCCT-3' \\
\hline FN1 & 5'-GCCAACAGGATGACATGAAT-3' & 5'-CATACCCGCCGAATGTAGGA-3' \\
\hline$\alpha 2 C O L-1$ & $5^{\prime}-\mathrm{TTGAGACTCAGCCACCCAGAGT-3'}$ & 5'-CAGTTCTTGGCTGGGATGTTTT-3' \\
\hline
\end{tabular}




\section{Results}

\section{Expression of SHH Signaling Pathway Components in Normal and IPF Lung Tissues}

The expression of SHH, PTC, and GLI1 was previously reported in IPF, 8,9,10 but the expression and patterns of other key members of the $\mathrm{HH}$ pathway have not been thoroughly examined. In addition, whether this pathway is expressed and operative in the normal adult lung is still unknown. Here, we detected the mRNA expression of the main components of the $\mathrm{HH}$ pathway $(\mathrm{SHH}, \mathrm{DHH}, \mathrm{IHH}$, PTC, HHIP, SMO, GLI1, GLI2, GLI3, SUFU, and SPOP) in both normal and IPF whole lung tissue extracts (Figure 1; see also Supplemental Figure S1 at http://ajp.amjpathol. org).

The relative mRNA expression of $\mathrm{SHH}$ and $\mathrm{IHH}$ was significantly lower in IPF than in control lung samples (mean decrease to $59 \%$ and $69 \%$, respectively; $P<$
0.01), with no significant difference in $\mathrm{DHH}$ mRNA level (Figure 1A; see also Supplemental Figure S1 at http:// ajp.amjpathol.org). Immunohistochemistry of SHH expression in normal and IPF tissue found $\mathrm{SHH}$ protein in the alveolar and bronchiolar epithelia of normal tissue (Figure 1B). In the IPF lung, SHH was expressed in the hyperplastic epithelium and in fibroblasts within the fibroblastic foci (Figure 1C) but was absent from nonfibrotic alveolar areas (see Supplemental Figure S1 at http://ajp. amjpathol.org). This paradoxical underexpression of $\mathrm{SHH}$ in "normal" alveolar territories in IPF could explain the significantly lower SHH mRNA level in IPF than in control homogenates. $\mathrm{SHH}$ protein level was similar in BALF (Figure 1D) from control patients (median, $87.4 \mathrm{pg} / \mathrm{mL}$; range, 18 to $160 \mathrm{pg} / \mathrm{mL}$ ) and patients with stable IPF (median, $86.9 \mathrm{pg} / \mathrm{mL}$; range, 22 to $242 \mathrm{pg} / \mathrm{mL}$ ). Interestingly, $\mathrm{SHH}$ protein level was significantly increased in BALF during acute IPF exacerbation (median, 139 pg/
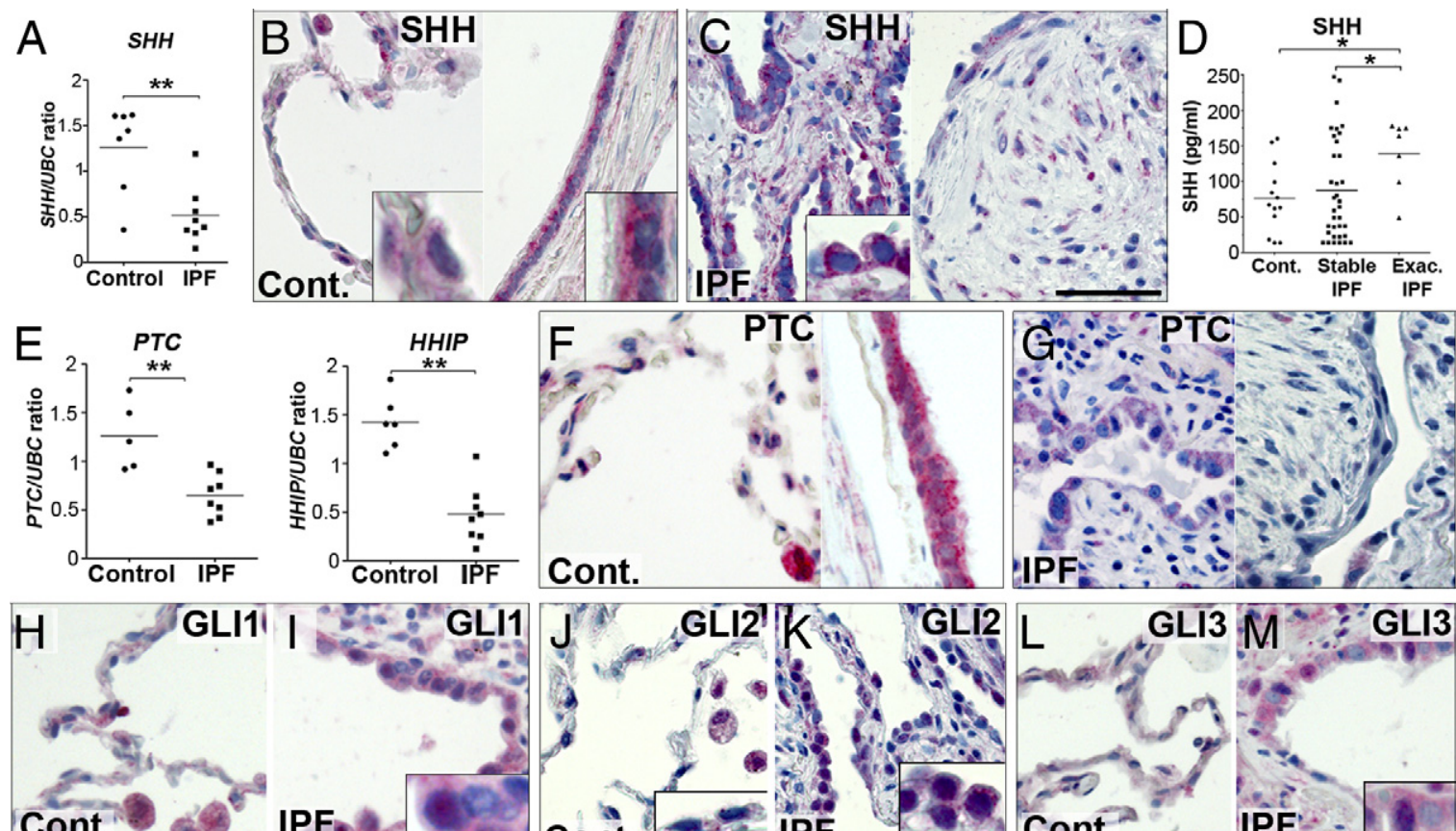

Cont.
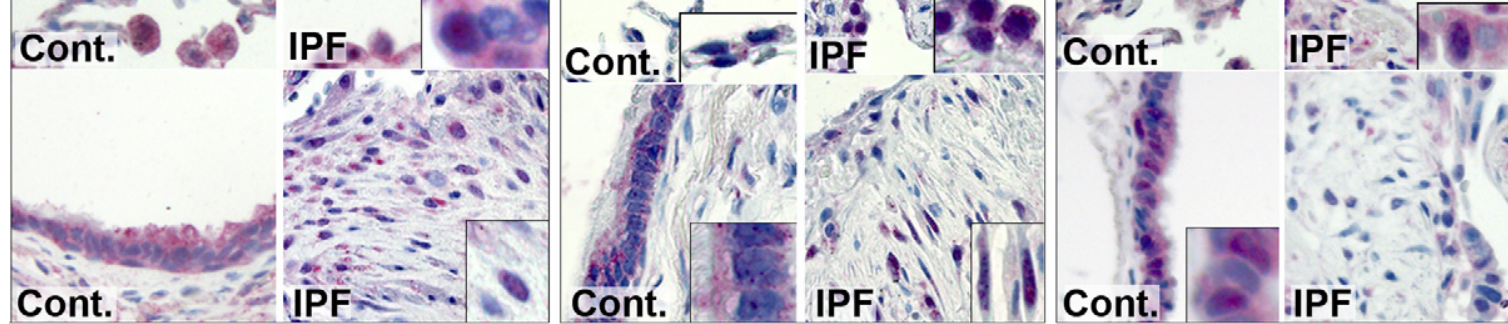

Figure 1. Expression of mammalian hedgehog $(\mathrm{HH})$ pathway proteins in control and IPF lung. A: Quantitative PCR of relative mRNA levels of Sonic hedgehog $(\mathrm{SHH})$ in whole lung extracts of control (circles) and IPF (squares) tissue. Levels are relative to that of ubiquitin $\mathrm{C}$ mRNA (UBC). ${ }^{* *} P<0.01$ compared ${ }^{2}$ ith control. B: Immunodetection (red staining) of SHH in alveolar (left panel) and bronchiolar (right panel) lung epithelia in control lung tissue. Nuclei were counterstained with hematoxylin. The insets show high magnification of cytoplasmic SHH staining in alveolar and bronchiolar epithelia. C: Immunodetection of SHH in hyperplastic epithelium (left panel) and fibroblast foci (right panel) in IPF lung tissue. The inset shows high magnification of cytoplasmic SHH staining in hyperplastic epithelium. D: SHH protein levels measured by ELISA in bronchoalveolar lavage fluid (BALF) of control patients (circles), patients with stable IPF (squares), and patients with exacerbated (Exac.) IPF (triangles). Shown are individual values and median (bars). " $P<0.05$. E: Quantitative PCR analysis of mRNA levels of PTC (left panel) and HHIP (right panel) in control (circles) and IPF (squares) whole lung extracts. Levels are relative to that of UBC mRNA. Shown are individual values and median (bars). ${ }^{* *} P<0.01$ compared with control. F: Immunodetection (red staining) of PTC in alveolar (left panel) and bronchiolar (right panel) lung epithelia in control lung tissues. Nuclei were counterstained with hematoxylin. G: Immunodetection of PTC in hyperplastic epithelium (left panel) and fibroblast foci (right panel) in IPF tissue. H-M: Immunodetection of GLI1 (H and I), GLI2 (J and K), and GLI3 (L and M) in control (H, J, and $\mathbf{L}$ ) and IPF (I, K, and $\mathbf{M}$ ) tissue. In control sections, the alveolar and bronchiolar epithelia are in the top and bottom panels, respectively. In IPF tissue, the hyperplastic epithelium and fibroblast foci are in the top and bottom panels, respectively. The insets show details of staining in the corresponding panels. Scale bars: $12 \mu \mathrm{m}(\mathbf{B}, \mathbf{C}, \mathbf{F}, \mathbf{G}, \mathbf{H}-\mathbf{M}) ; 6 \mu \mathrm{m}$ (insets). 
$\mathrm{mL}$; range, 49 to $178 \mathrm{pg} / \mathrm{mL} ; P<0.05)$ compared with control and stable IPF samples (Figure 1D). Therefore, the ligand $\mathrm{SHH}$ was present in fibrotic areas of IPF, although the level depended on the area studied.

We also assayed the mRNA expression of PTC and $\mathrm{HHIP}$ (two receptors of $\mathrm{SHH}$ ) that are inhibitors of the $\mathrm{HH}$ pathway. ${ }^{4}$ PTC and HHIP levels were lower in IPF than in normal lung tissue (mean decrease $49 \%$ and $67 \%$, respectively; $P<0.01$ ) (Figure 1E). PTC protein expression was detected in alveolar and bronchiolar epithelia and in alveolar macrophages in normal lung tissue (Figure 1F). In IPF, PTC was expressed in the hyperplastic epithelium, ${ }^{8,9}$ but staining intensity was weaker in the IPF than in normal lung epithelium (Figure 1G). The mRNA level of SMO was similar between normal and IPF lungs (see Supplemental Figure S1 at http://ajp.amjpathol.org). In normal lung tissue, SMO staining was observed in the alveolar and bronchiolar epithelia, whereas in IPF the hyperplastic epithelium broadly expressed SMO. SMOpositive cells were also detected in fibroblastic foci (see Supplemental Figure S1 at $h$ ttp://ajp.amjpathol.org). Thus, IPF tissue showed down-regulated HH pathway inhibitors (PTC and HHIP) but maintained the expression of SMO, the required signal transducer of the pathway.

Next, we assayed the expression of GLI transcription factors downstream of SMO activation. The mRNA levels of GLI1, GLI2, and GLI3 did not significantly differ between control and IPF lung tissue (see Supplemental Figure S1 at $h$ ttp://ajp.amjpathol.org). Alveolar and bronchiolar epithelia were positive for GLI1. GLI1 staining was exclusively cytoplasmic in normal lung tissues (Figure $1 \mathrm{H}$ ), but GLI1 staining was nuclear in the hyperplastic epithelium and fibroblastic foci in IPF tissue (Figure 1I). The expression patterns of GLI2 and GLI1 were similar in normal and IPF lung sections (Figure $1, \mathrm{~J}$ and $\mathrm{K}$ ). Most importantly, GLI2 showed a nuclear expression pattern in nonfibrotic alveolar areas in IPF lungs (see Supplemental Figure S1 at $h$ ttp://ajp.amjpathol.org). The nuclear localization of GLI1 and GLI2 is a marker of active HH signaling, ${ }^{4,8}$ so the $\mathrm{HH}$ pathway was probably activated early in the fibrotic process in alveolar epithelial cells.

GLI3 is the prototypic repressor-GLI transcription factor. In the normal lung, GLI3 staining was cytoplasmic in the alveolar epithelium and nuclear in the bronchiolar epithelium (Figure 1L). Nuclear GLI3 staining was detected in some hyperplastic alveolar epithelial cells but was weak in fibroblast foci (Figure 1M). The low expression of GLI3 was concordant with global activation of the pathway. Activation of the pathway was supported by detection of Cyclin D1 and BCL-2, two targets of the $\mathrm{HH}$ pathway, ${ }^{16,17}$ at sites corresponding to nuclear localization of GLI1/2 (see Supplemental Figure S1 at http:// ajp.amjpathol.org).

The mRNA expression of SUFU and SPOP, which regulate GLI levels posttranscriptionally in the cytoplasm, ${ }^{7}$ was decreased in IPF tissue (mean decrease to 59\% and $69 \%$, respectively; $P<0.05$; see Supplemental Figure S1 at http://ajp.amjpathol.org). In the normal lung, SUFU staining was cytoplasmic in the alveolar and bronchiolar epithelia (see Supplemental Figure S1 at http://ajp. amjpathol.org), but in IPF tissue SUFU staining was nuclear in the hyperplastic epithelium (see Supplemental Figure S1 at $h$ ttp://ajp.amjpathol.org). SUFU nuclear localization is an indication of $\mathrm{HH}$ pathway activation in IPF because SUFU is thought to regulate GLI nuclear/cytoplasmic transport in the cell. ${ }^{4}$

Our results indicated that the $\mathrm{HH}$ system was largely expressed in the normal alveolar epithelium and was activated in IPF tissue in the hyperplastic epithelium and within the fibroblastic foci (Table 2).

\section{Control and IPF Lung Fibroblasts Express HH Pathway Components in Vitro}

Fibroblasts play a key role in the development of lung fibrosis. In light of the activation of the $\mathrm{HH}$ pathway in myofibroblasts in situ within the fibroblast foci in IPF lungs, we first studied the expression of the different components of $\mathrm{HH}$ signaling in primary HLFs from control and IPF lung explants. The mRNA expression of $S H H$, $I H H$, and $D H H$ was absent in both control and IPFs (data not shown), whereas control and IPF fibroblasts expressed similar levels of PTC, SMO, GLI1, GLI2, GLI3, and SUFU mRNA in serum-deprived culture condition (see Supplemental Figure S2 at http://ajp.amjpathol.org).

\section{SMO Basal Activity Is Required to Maintain Control and IPF Fibroblast Proliferation and Differentiation}

Next, we evaluated whether basal $\mathrm{HH}$ pathway activity was required for fibroblast proliferation and maintaining a basal myofibroblast phenotype. Here, we used CYC, a wellcharacterized, naturally occurring inhibitor of SMO. ${ }^{18}$ Control and IPFs were treated with vehicle or $5 \mu \mathrm{mol} / \mathrm{L}$

Table 2. Comparison of Quantitative PCR Analysis of mRNA Level and Immunohistochemistry of Hedgehog System Components in Paraffin Sections of Idiopathic Pulmonary Fibrosis Compared with Control Counterparts

\begin{tabular}{|c|c|c|}
\hline Hedgehog pathway & $\begin{array}{l}\text { mRNA } \\
\text { level }\end{array}$ & Immunostaining \\
\hline \multicolumn{3}{|l|}{ Positive regulators } \\
\hline $\mathrm{SHH}$ & $\downarrow$ & $\begin{array}{l}\text { Positive in fibrotic } \\
\text { lesions; } \downarrow \text { in "normal" } \\
\text { areas }\end{array}$ \\
\hline $\mathrm{IHH}$ & $\downarrow$ & ND \\
\hline $\mathrm{DHH}$ & $=$ & ND \\
\hline SMO & $=$ & $=$ \\
\hline GLI1 & $=$ & Nuclear in fibrotic lesions \\
\hline GLI2 & $=$ & $\begin{array}{l}\text { Nuclear in fibrotic lesions } \\
\text { and in "normal" areas }\end{array}$ \\
\hline SUFU & $\downarrow$ & Nuclear in fibrotic lesions \\
\hline \multicolumn{3}{|l|}{ Negative regulators } \\
\hline PTC & $\downarrow$ & $\downarrow$ in fibrotic lesions \\
\hline HHIP & $\downarrow$ & ND \\
\hline GLI3 & $=$ & $\downarrow$ in fibrotic lesions \\
\hline SPOP & $\downarrow$ & ND \\
\hline
\end{tabular}

$\downarrow$, decreased compared with control lung tissue; =, unchanged; ND, not determined. 
A
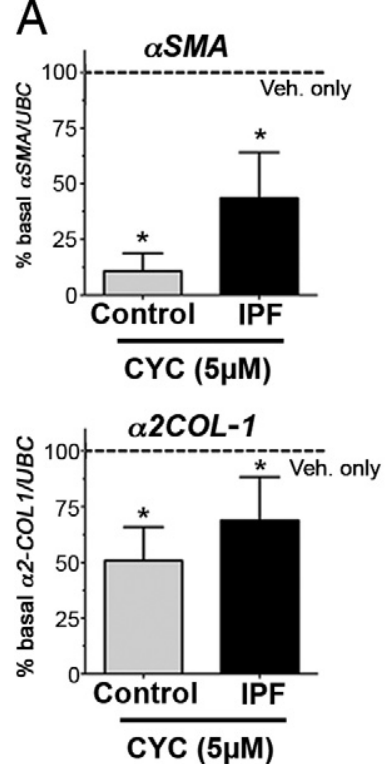

FN1

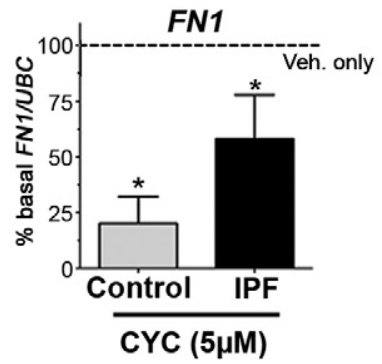

Figure 2. Effect of SMO inhibition by CYC on basal expression of myofibroblast differentiation markers in control and IPF human lung fibroblasts (HLFs). A: Quantitative PCR analysis of mRNA levels of $\alpha$-SMA, $\alpha 2$ COL-1, and FN1 in control and IPF HLFs treated with CYC $(5 \mu \mathrm{mol} / \mathrm{L})$ and cells treated with vehicle alone (dashed line) for 48 hours. Levels are relative to that of Ubiquitin C mRNA. Data are mean \pm SEM of seven samples per group. ${ }^{*} P<$ 0.05. B: Representative Western blot analysis of the effect of CYC $(5 \mu \mathrm{mol} / \mathrm{L}$ for 48 hours) on the basal protein levels of $\alpha$-SMA, COL-1, and FN1 in control and IPF HLFs. The arrows show $\alpha 1$ and $\alpha 2$ COL- 1 isoforms. GAPDH was a loading control.

CYC for 48 hours. CYC inhibited to the same extent the proliferation of control and IPF fibroblasts (see Supplemental Figure S3 at http://ajp.amjpathol.org). CYC strongly decreased the basal mRNA levels of $\alpha$-SMA, $\alpha 2 \mathrm{COL}-1$, and FN1 in control and IPF HLFs compared with vehicle treatment in vitro (Figure $2 \mathrm{~A}$ ). These results were confirmed at the protein level by immunoblot (Figure 2B). Therefore, SMO basal activity was required to maintain the proliferation and basal expression of myofibroblastic markers in control and IPF fibroblasts in vitro.

\section{TGF- $\beta 1$ Stimulation Modulates the Expression of Key Components of the HH System in Control and IPF HLFS}

Because activation of the TGF- $\beta 1$ pathway is central to the fibrotic process, we investigated whether SMO activity was required for TGF- $\beta 1$-induced myofibroblastic differentiation. A cross talk between the $\mathrm{HH}$ and TGF- $\beta$ pathways was previously described in that TGF- $\beta 1$ treatment induced the mRNA expression of GLI1 and GLI2 in a SMAD3-dependent manner in dermal fibroblasts $^{19}$ and pancreatic ductal adenocarcinoma cells. ${ }^{20}$

We first assayed the effects of TGF- $\beta 1$ on the expression of different components of the $\mathrm{HH}$ system in HLFs. TGF- $\beta 1$ treatment ( $1 \mathrm{ng} / \mathrm{mL}$ for 48 hours) decreased the mRNA level of PTC, inhibitor of SMO, in both control and IPF fibroblasts (Figure 3A) and as early as 4 hours after treatment (see Supplemental Figure S4 at http://ajp. amjpathol.org). This decrease was abolished in the presence of protein synthesis inhibitor $\mathrm{CHX}$ (see Supplemental Figure S4 at http://ajp.amjpathol.org). TGF- $\beta 1$ de-
A

PTC

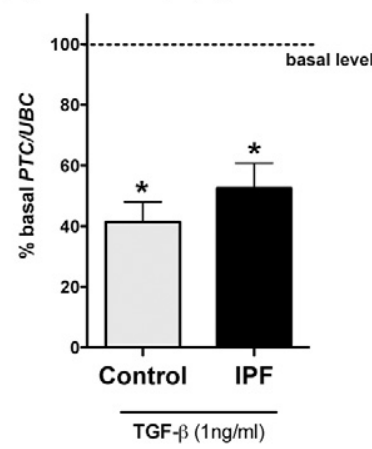

C
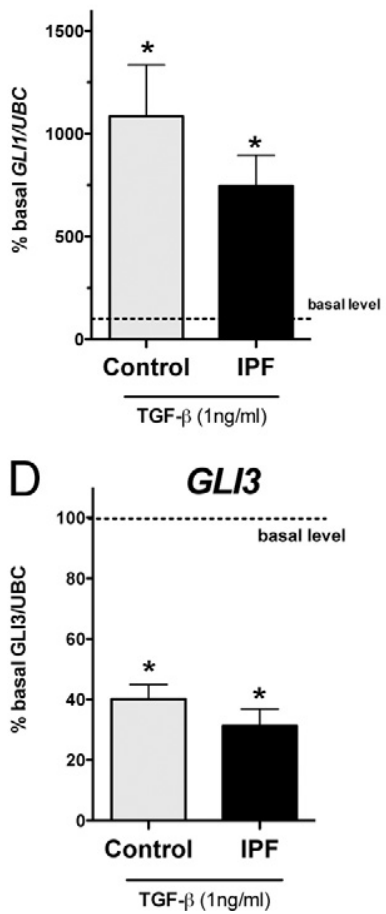

B SMO

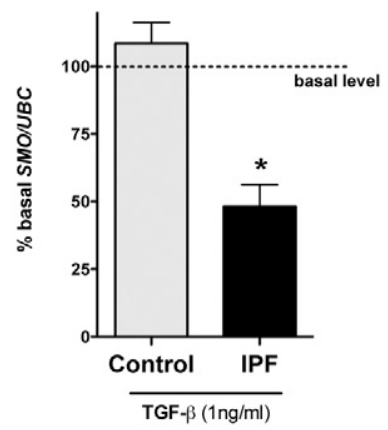

GLI2

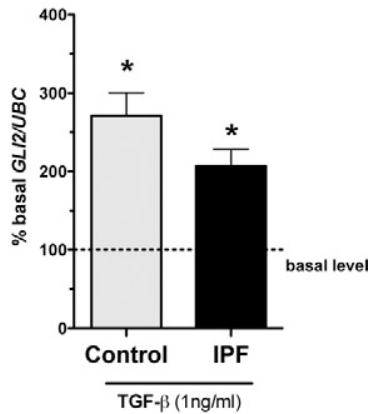

E

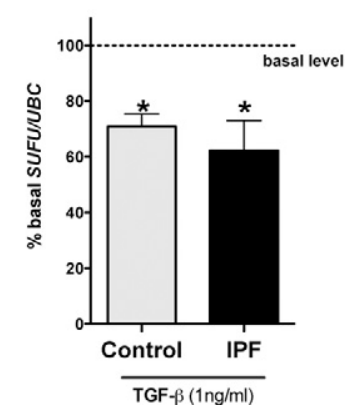

Figure 3. Effect of TGF- $\beta 1$ on the expression of HH system components in control and IPF HLFs. Quantitative PCR analysis of relative mRNA levels of PTC (A), SMO (B), GLI1, GLI2 (C), GLI3 (D), and SUFU (E) in control and IPF HLFs with TGF- $\beta 1$ ( $1 \mathrm{ng} / \mathrm{mL}$ for 48 hours) and unstimulated cells (basal level, dashed line). Levels are relative to that of Ubiquitin $\mathrm{C}$ (UBC) mRNA. Data are mean \pm SEM from five to seven samples per group. ${ }^{*} P<$ 0.05 . 


\section{A Control HLF}
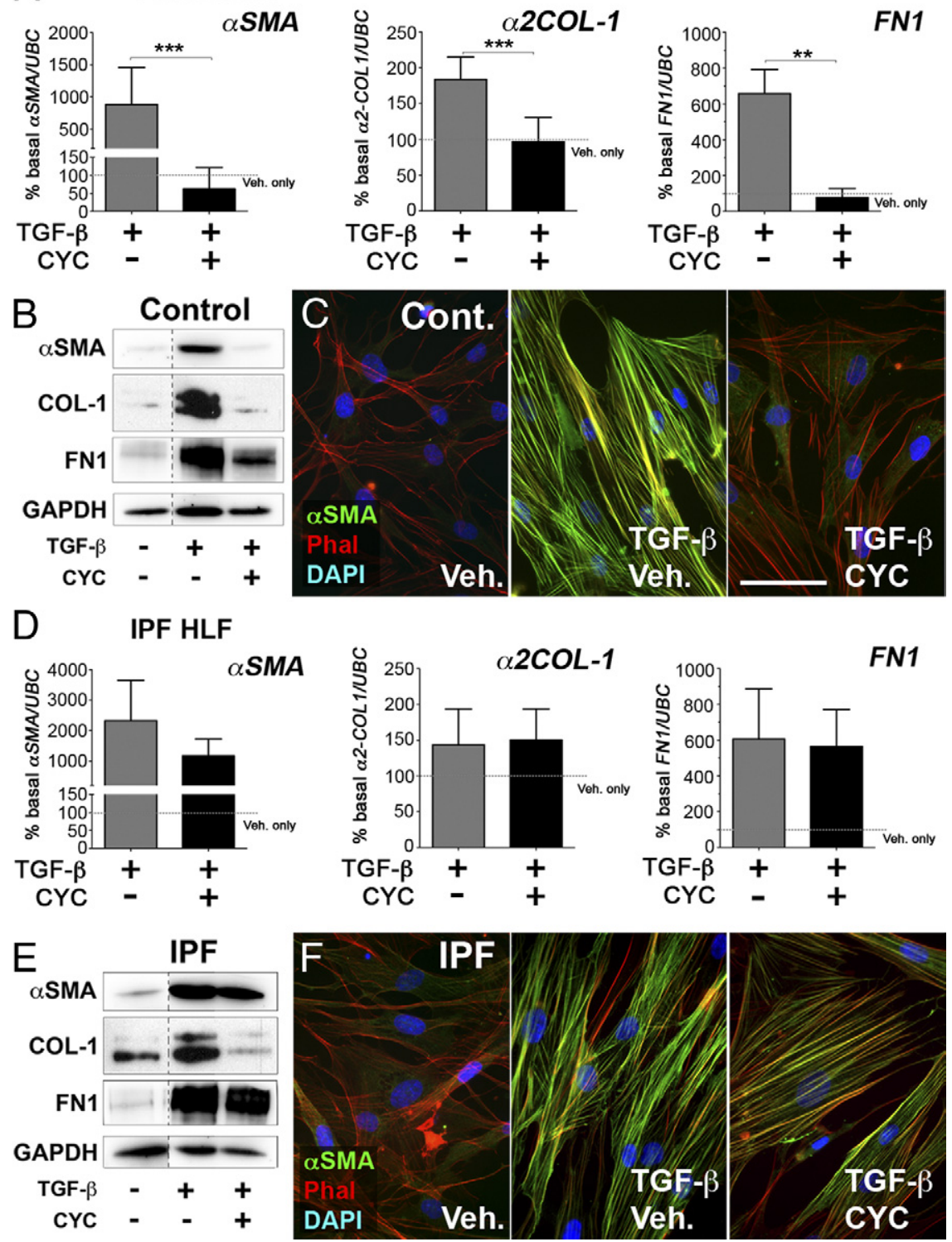

Figure 4. Effect of SMO inhibition by CYC on TGF$\beta 1$-induced myofibroblastic differentiation in control and IPF HLFs. A: Quantitative PCR analysis of relative mRNA levels of $\alpha$-SMA, $\alpha 2$ COL-1, and FN1 in control HLFs with TGF- $\beta 1$ at $1 \mathrm{ng} / \mathrm{mL}$ with or without $\mathrm{CYC}$ at $5 \mu \mathrm{mol} / \mathrm{L}$ compared with vehicle alone (dashed line) for 48 hours. Levels are relative to that of Ubiquitin C (UBC) mRNA. Data are mean \pm SEM from seven samples per group. ${ }^{* *} P<0.01$, ${ }^{* * *} P<$ 0.001. B: Representative Western blot analysis of the effect of CYC $(5 \mu \mathrm{mol} / \mathrm{L})$ on the protein levels of $\alpha$-SMA, COL- 1 , and FN1 in control and IPF HLFs with TGF- $\beta 1(1 \mathrm{ng} / \mathrm{mL})$ for 48 hours. GAPDH was a loading control. C: Immunofluorescence assay of $\alpha$-SMA (green), actin fibers stained with phalloidin (red) and DNA stained with DAPI (blue) in control HLFs with vehicle alone (left panel); vehicle and 1 $\mathrm{ng} / \mathrm{mL}$ TGF- $\beta 1$ (middle panel); $5 \mu \mathrm{mol} / \mathrm{L} \mathrm{CYC} \mathrm{and}$ $1 \mathrm{ng} / \mathrm{mL}$ TGF- $\beta 1$ (right panel) for 48 hours. D: Quantitative PCR analysis of relative mRNA levels of $\alpha$-SMA, $\alpha 2$ COL- 1 , and FN1 in IPF HLFs with TGF- $\beta 1$ at $1 \mathrm{ng} / \mathrm{mL}$ with or without CYC at $5 \mu \mathrm{mol} / \mathrm{L} \mathrm{com}-$ pared with vehicle alone (dashed line) for 48 hours. Levels are relative to that of UBC mRNA. Data are mean \pm SEM from seven samples per group. E: Representative Western blot analysis of the effect of CYC $(5 \mu \mathrm{mol} / \mathrm{L})$ on the protein levels of $\alpha$-SMA, COL-1, and FN1 in control and IPF HLFs with TGF- $\beta 1(1 \mathrm{ng} / \mathrm{mL})$ for 48 hours. GAPDH was a loading control. F: Immunofluorescence assay of $\alpha$-SMA (green), actin fibers stained with phalloidin (red), and DNA stained with DAPI (blue) in IPF HLFs with vehicle alone (left panel), vehicle and $1 \mathrm{ng} / \mathrm{mL}$ TGF- $\beta 1$ (middle panel), $5 \mu \mathrm{mol} / \mathrm{L}$ CYC and 1 $\mathrm{ng} / \mathrm{mL}$ TGF- $\beta 1$ (right panel) for 48 hours. Scale bars: $30 \mu \mathrm{m}(\mathbf{C}-\mathbf{F})$.

creased the basal mRNA level of SMO (Figure 3B) in IPF HLFs only but greatly increased the basal mRNA levels of GLI1 and GLI2 in both control and IPF HLFs (Figure 3C). GLI1 mRNA up-regulation was a late event (from 16 hours) and was inhibited by $\mathrm{CHX}$ in both control and IPF HLFs (see Supplemental Figure S4 at http://ajp. amjpathol.org), which suggested an indirect mRNA upregulation of GLI1. In contrast, GLI2 mRNA up-regulation was observed after 4 hours of treatment and was not inhibited by CHX in control or IPF HLFs (see Supplemental Figure S4 at http://ajp.amjpathol.org), which suggested a direct mRNA up-regulation of GLI2 downstream of TGF- $\beta$ pathway activation in HLFs. TGF- $\beta$ strongly decreased the basal mRNA level of GLI3, the inhibitory GLI transcription factor (Figure 3D) but only slightly inhibited the mRNA level of SUFU in both control and IPF HLFs (Figure 3E). Finally, inhibition of SMO activity with CYC did not modulate the effects of TGF- $\beta 1$ on the mRNA levels of PTC, SMO, GLI1, GLI2,
GLI3, and SUFU in HLFs (data not shown). Thus, TGF- $\beta 1$ output on the $\mathrm{HH}$ system aimed for activation in a SMO-independent manner.

\section{TGF- $\beta 1$-Induced Fibroblast Differentiation Depends on SMO in Control, But Not IPF, Fibroblasts}

Next, we asked whether $\mathrm{HH}$ signaling was involved in myofibroblast differentiation induced by TGF- $\beta 1$. Control and IPF fibroblasts were treated with TGF- $\beta 1$ ( $1 \mathrm{ng} / \mathrm{mL}$ ) with or without different $\mathrm{HH}$ pathway pharmacologic antagonists for 48 hours.

In TGF- $\beta 1$-stimulated control HLFs, inhibition of SMO activity with $5 \mu \mathrm{mol} / \mathrm{L}$ CYC inhibited the mRNA and protein up-regulation of $\alpha$-SMA, COL-1, and FN1 induced by TGF- $\beta 1$ (Figure $4, A$ and $B$ ) and strongly decreased the formation of stress fibers associated 


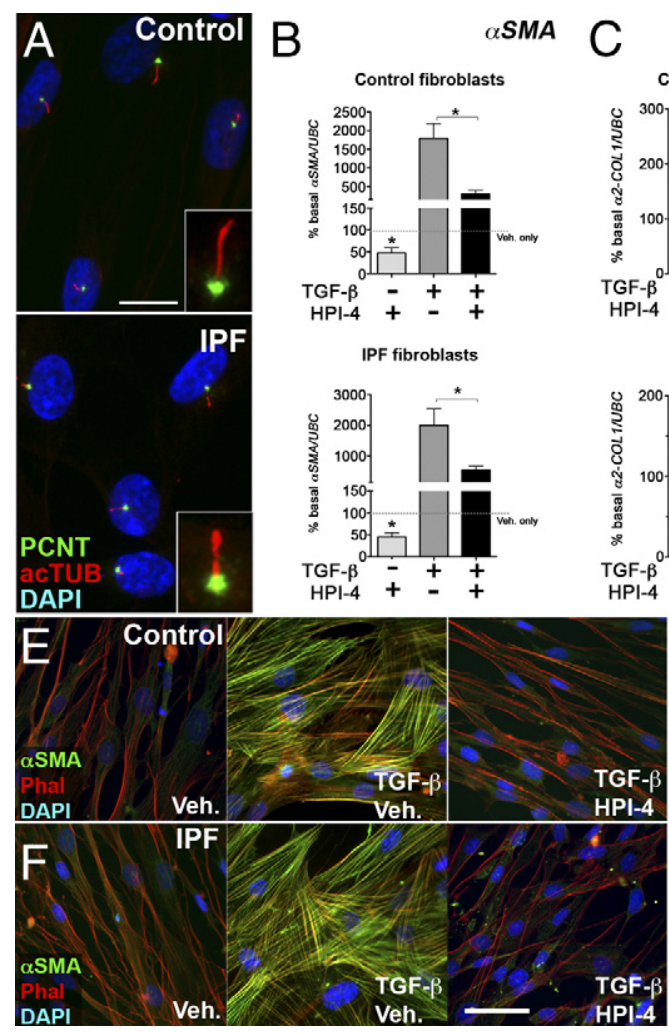

with $\alpha$-SMA as assessed by immunofluorescence (Figure 4 C). However, IPF HLFs were partially resistant to CYC, because it did not inhibit the mRNA up-regulation of $\alpha$-SMA, $\alpha 2 \mathrm{COL}-1$, and FN1 with TGF- $\beta 1$ treatment (Figure 4D) and did not significantly inhibit the increased protein levels of $\alpha$-SMA and FN1 induced by TGF- $\beta 1$ (Figure 4, E and F). Interestingly, CYC inhibited the protein level of COL-1 induced by TGF- $\beta 1$ in IPF HLFs (Figure 4E), which suggested a posttranscriptional action of CYC. In a set of control experiments, we confirmed that CYC did not inhibit the phosphorylation or nuclear translocation of SMAD3 downstream of TGF- $\beta 1$ stimulation in control or IPF HLFs (see Supplemental Figure S5 at http://ajp.amjpathol.org).

Our results showed that SMO activity was required for TGF- $\beta$-induced myofibroblastic differentiation in control HLFs, whereas IPF HLFs were partially resistant to SMO inhibition with TGF- $\beta 1$ stimulation. The TGF- $\beta$ pathway could bypass the normal $\mathrm{SHH} / \mathrm{SMO}-$ driven regulation of the $\mathrm{HH}$ pathway in IPF fibroblasts, and GLI activation in IPF could be directly downstream of TGF- $\beta 1$, independent of an $\mathrm{SHH}$ ligand.

\section{GLI Activation at the Primary Cilium and Nuclear Activity Is Required for TGF- $\beta 1$-Induced Myofibroblast Differentiation in Control and IPF Fibroblasts}

To further decipher the involvement of the $\mathrm{HH}$ pathway in TGF- $\beta$-induced myofibroblastic differentiation, we inhibited the $\mathrm{HH}$ signaling pathway downstream of SMO from
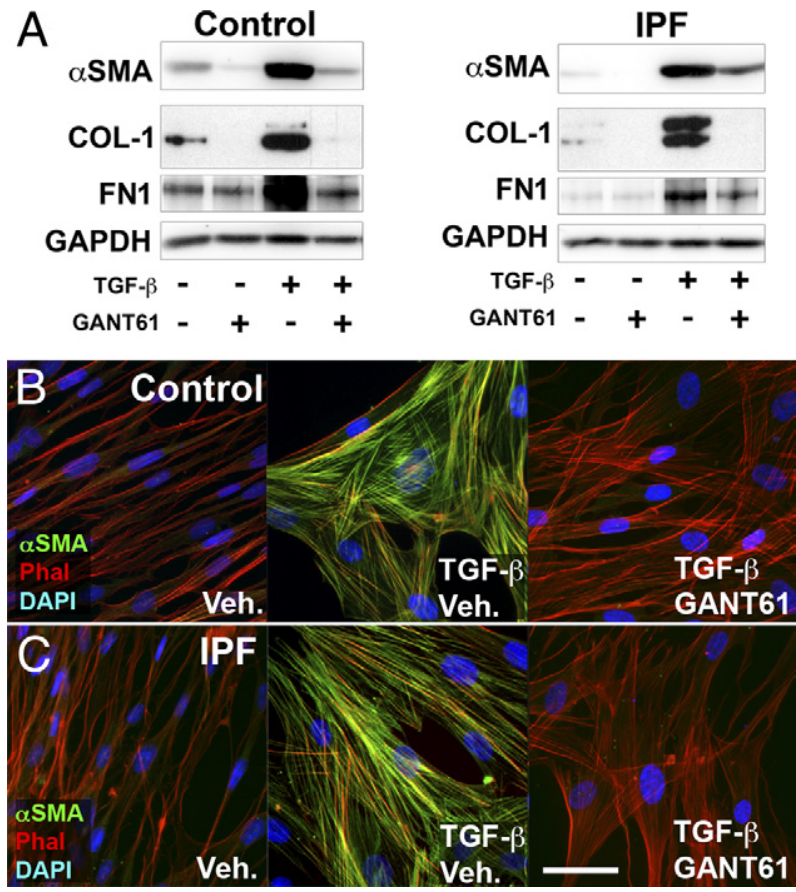

Figure 6. Effects of GANT61 on TGF- $\beta 1$-induced myofibroblasts differentiation in control and IPF HLFs. A: Representative Western blot analysis of the effect of GANT61 $(5 \mu \mathrm{mol} / \mathrm{L})$ on protein levels of $\alpha$-SMA, COL-1, and FN1 in control and IPF HLFs with vehicle alone, GANT61 alone, TGF- $\beta 1$ ( $1 \mathrm{ng} / \mathrm{mL}$ ) alone, or costimulated with TGF- $\beta 1$ and GANT61 for 48 hours. GAPDH was a loading control. B and C: Immunofluorescence assay of $\alpha$-SMA (green), actin fibers stained with phalloidin (red), and nuclei stained with DAPI (blue) in control (B) and IPF (C) HLFs with vehicle alone (left panel), vehicle and TGF- $\beta 1$ (middle panel); GANT61 at $5 \mu \mathrm{mol} / \mathrm{L}$, and TGF- $\beta 1$ at $1 \mathrm{ng} / \mathrm{mL}$ (right panel) for 48 hours. Scale bars: $30 \mu \mathrm{m}(\mathbf{B}$ and $\mathbf{C})$ 

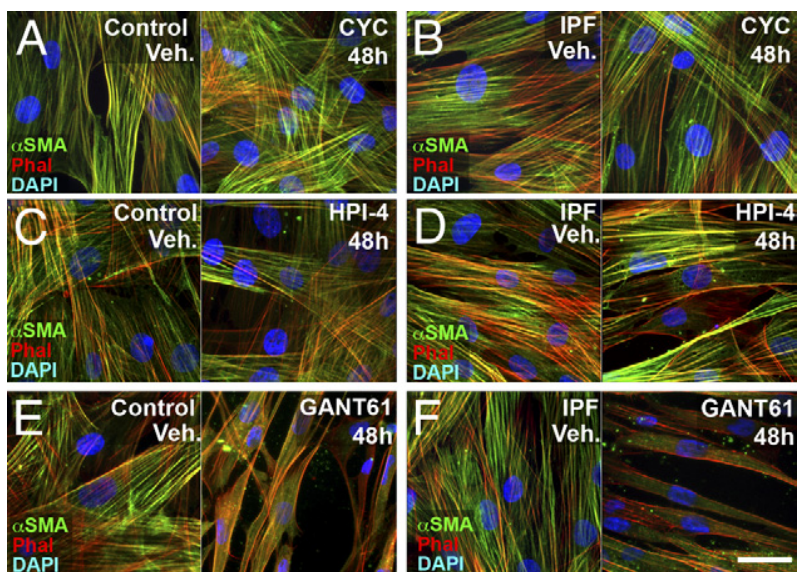

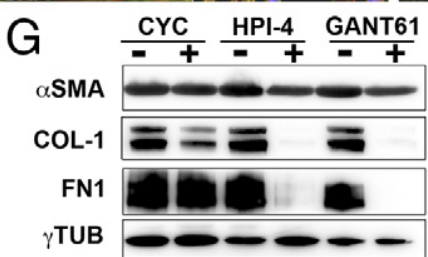

Control TGF- $\beta 1$ HLF
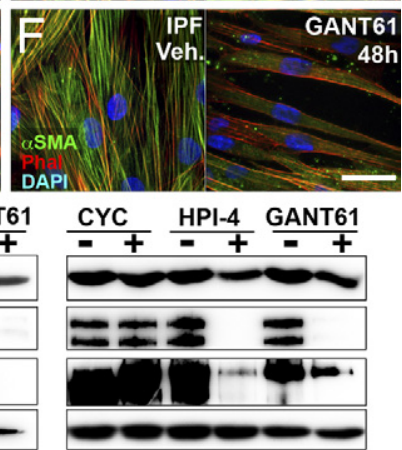

IPF TGF- $\beta 1$ HLF $\mathbf{t}=72 \mathrm{~h}$

Figure 7. Effect of CYC, hedgehog pathway inhibitor (HPI-4), and GANT61 on control and IPF myofibroblasts differentiated with TGF- $\beta 1$. A-F: Representative immunofluorescence images of control (A) and IPF (B) differentiated myofibroblasts with vehicle alone or CYC at $5 \mu \mathrm{mol} / \mathrm{L}$ for 48 hours Control (C) and IPF (D) differentiated myofibroblasts with vehicle alone (left panel) or HPI- 4 at $20 \mu \mathrm{mol} / \mathrm{L}$ (right panel) for 48 hours. Control (E) and IPF (F) differentiated myofibroblasts with vehicle alone (left panel) or GANT61 at $5 \mu \mathrm{mol} / \mathrm{L}$ (right panel) for 48 hours. Images show overlay of $\alpha$-SMA (green), actin fibers stained with phalloidin (red), and nuclei stained with DAPI (blue). G: Representative Western blot analysis of the effect of CYC (5 $\mu \mathrm{mol} / \mathrm{L}), \mathrm{HPI}-4(20 \mu \mathrm{mol} / \mathrm{L})$, and GANT61 $(5 \mu \mathrm{mol} / \mathrm{L})$ on the protein levels of $\alpha$-SMA. COL-1, and FN1 in differentiated control and IPF HLFs for 48 hours. $\gamma$-Tubulin $(\gamma$ TUB) was a loading control. Scale bars: $30 \mu \mathrm{m}(\mathbf{A}-\mathbf{E})$.

the primary cilium with HPI-4 or GANT61. Because the primary cilium plays a critical role in the $\mathrm{HH}$ system, ${ }^{4}$ we checked that control and IPF HLFs displayed a primary cilium in vitro (Figure 5A). HPI-4 and GANT61 molecules were identified in cell-based small molecule screens for $\mathrm{HH}$ pathway inhibitors downstream of SMO activation. ${ }^{21,22} \mathrm{HPI}-4$ can perturb ciliogenesis, thus leading to disrupted GLI1/GLI2 activation. ${ }^{21}$ Meanwhile, GANT61 can inhibit the $\mathrm{HH}$ pathway by directly blocking the binding of GLI1 and GLI2 to their DNA targets. ${ }^{22}$ Like CYC, HPI-4 (20 $\left.\mu \mathrm{mol} / \mathrm{L}\right)$ and GANT61 (5 $\mu \mathrm{mol} / \mathrm{L})$ reduced the proliferation of both control and IPF HLFs in complete growth medium compared with vehicle alone (see Supplemental Figure S3 at http:// ajp.amjpathol.org)

$\mathrm{HPI}-4$ treatment inhibited the basal mRNA expression level of $\alpha$-SMA and strongly reduced the mRNA and protein up-regulation of $\alpha$-SMA with TGF- $\beta 1$ stimulation in both control and IPFs compared with TGF- $\beta 1$ alone (Figure $5, \mathrm{~B}$ and $\mathrm{E}-\mathrm{G}$ ). $\mathrm{HPI}-4$ did not significantly modify the mRNA levels of ECM proteins $\alpha 2 \mathrm{COL}-1$ and FN1 with TGF- $\beta 1$ stimulation (Figure $5, \mathrm{C}$ and $\mathrm{D}$ ) but did reduce COL-1 and FN1 protein levels with basal and TGF- $\beta 1$ stimulation in control and IPF HLFs (Figure 5G), which suggested posttranscriptional action of HPI-4. Similar to $\mathrm{HPI}-4$, inhibition of GLI transcriptional activity with
GANT61 completely abrogated the effect of TGF- $\beta$ on the protein levels of $\alpha$-SMA, COL-1, and FN1 in both control and IPF HLFs (Figure 6, A-C).

Thus, inhibition of GLI activation in the primary cilium with $\mathrm{HPI}-4$, as well as GLI transcriptional activity in the nucleus with GANT61, fully prevented TGF- $\beta 1$-induced myofibroblast differentiation in control and IPF HLFs. In contrast with CYC, both control and IPF HLF were sensitive to HPI-4 and GANT61 at the same extent.

\section{Inhibition of GLI Activity by HPI-4 and GANT61 Partially Reverts the Myofibroblast Phenotype of Differentiated Control and IPF HLFs in Vitro}

Finally, we asked whether inhibition of the $\mathrm{HH}$ pathway with CYC, HPI-4, and GANT61 could revert the phenotype of control and IPF myofibroblasts fully differentiated in vitro with TGF- $\beta 1$ for 48 hours. Control and IPF differentiated myofibroblasts treated with CYC or HPI-4 for 48 and 72 hours still showed a typical myofibroblastic shape, with $\alpha$-SMA-positive stress fibers at 48 hours (Figure 7, A-D). Meanwhile, inhibition of GLI transcription factors in the nucleus with GANT61 completely reverted the differentiation of both control and IPF myofibroblasts compared with vehicle alone (Figure 7, E and F). After

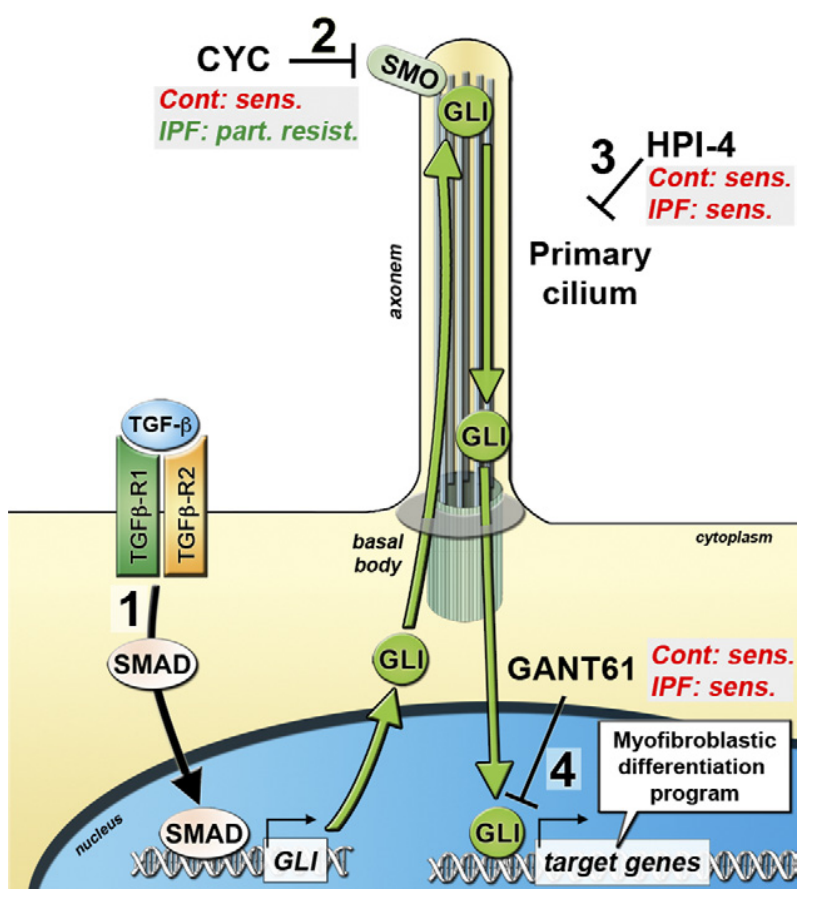

Figure 8. Model of the cross talk between the TGF- $\beta 1$ and HH pathways during myofibroblastic differentiation of control and IPF HLFs. Model of the cross talk between the HH and TGF- $\beta 1$ pathways. During myofibroblastic differentiation, TGF- $\beta 1$ induces GLI activators independently of Smoothened (SMO) activity in both control and IPF HLFs (1). This up-regulation is probably mediated by SMAD $3 .{ }^{19}$ Downstream of TGF- $\beta 1$-induced $G L I$ upregulation, the canonical GLI pathway is still required. The inhibition of the pathway at the level of SMO with cyclopamine (CYC) (2) inhibited the differentiation with TGF- $\beta 1$ treatment in control HLFs and IPF HLFs were partially resistant. Inhibition of the canonical GLI pathway at the primary cilium with hedgehog pathway inhibitor (HPI-4) (3) or in the nucleus with GANT-61 (4) completely abrogated TGF- $\beta 1$-induced myofibroblastic differentiation in both cell types. Abbreviations: control (cont), sensitive (sens.), partially resistant (part. Resist.) 
GANT61 treatment, control and IPF HLFs showed a typical fibroblastic spindle shape, with no $\alpha$-SMA-positive stress fibers at 48 hours. However, diffuse cytoplasmic $\alpha$-SMA staining was still observed in cells treated with GANT61 at 48 hours (Figure 7, E and F). SMO inhibition with $C Y C$ did not decrease the protein expression of $\alpha$-SMA, COL-1, and FN1 in control or IPF-differentiated HLFs after 72 hours (Figure 7G). Inhibition of GLI activation with HPI-4 or GANT61 slightly decreased $\alpha$-SMA in both cell types only at 72 hours (Figure 7G). However, HPI-4 or GANT61 strongly inhibited the expression of COL-1 and FN1 at 72 hours in both control and IPF-differentiated HLFs (Figure 7G). These data strongly suggested that GLI activity was required to maintain the phenotype of both control and IPF myofibroblasts, in particular ECM synthesis, independent of SMO.

\section{Discussion}

Our results strongly suggest that activation of the $\mathrm{HH}$ system may play a critical role in IPF pathophysiology. We found that (1) the $\mathrm{HH}$ pathway is reactivated in IPF lung tissue; (2) TGF- $\beta 1$, a major mediator of pulmonary fibrosis, modulates the expression of key components of the $\mathrm{HH}$ pathway in HLFs in vitro; (3) SMO activity is required for myofibroblast differentiation of control HLFs with TGF- $\beta 1$ stimulation, but IPF HLFs are partially resistant to SMO inhibition; and (4) GLI activity from the primary cilium is required to induce and maintain myofibroblast differentiation of both control and IPF HLFs in vitro (see model in Figure 8).

\section{Activation of the HH System in IPF}

The HH system plays a critical role during lung development. ${ }^{5,23}$ Growing evidence suggests that several key signaling pathways during development such as the TGF- $\beta / \mathrm{SMAD}^{3}$ and WNT/ $\beta$-Catenin ${ }^{24-26}$ pathways are aberrantly expressed in IPF. These pathways are involved in perturbed epithelial-mesenchymal interactions in IPF, thus leading to an impaired repair process and disease progression. ${ }^{1,3}$ Our study, focusing on the $\mathrm{HH}$ pathway, supports that not a single input but rather complex interactions between multiple reactivated developmental signaling pathways (eg, WNT, TGF- $\beta$, FGF, SHH, $\mathrm{NOTCH}$, etc) probably dictate the abnormal cellular responses in IPF. 1,3,25,26

$\mathrm{SHH}$ was found expressed in the altered epithelium of interstitial lung diseases such as cryptogenic organizing pneumonia and nonspecific and usual interstitial pneumonitis, ${ }^{8,9}$ but the expression in normal tissue was not known. Our data suggest that the HH/GLI system is expressed in the adult lung but is activated in the IPF lung and repressed in the normal lung. Indeed, the lack of GLI1 and GLI2 nuclear staining in the distal epithelium, associated with preferential staining for nuclear GLI3 (the repressor transcription factor) in the bronchiolar epithelium, indicates that the $\mathrm{HH}$ pathway was inhibited in the control lung. By contrast, the $\mathrm{HH}$ pathway was activated in the stable IPF lung compared with the normal lung (see Table 2). The expression of PTC and HHIP was lower in the IPF than in the control lung, which contributes to decreased inhibition on SMO activation (see canonical $\mathrm{HH}$ pathway model in Supplemental Figure S1 at $h t t p: / /$ ajp.amjpathol.org). SMO expression was similar between control and IPF lungs. Nuclear localization of GLI1 and GLI2, the final and bona fide hallmark of $\mathrm{HH}$ pathway activation, was detected only in IPF lungs, particularly at the level of the hyperplastic alveolar epithelium and within fibroblastic foci. We also observed the expression of GLI target genes such as Cyclin D127 and BCL-2 ${ }^{28}$ in IPF tissue. Unlike BCL-2, Cyclin D1 was not detected in nonproliferating GLIpositive areas such as fibrotic foci, which suggests that additional signals are required to control Cyclin D1 expression in the IPF lung. For instance, Cyclin D1 is also described as a WNT/ $\beta$-catenin-regulated gene, ${ }^{27}$ which again indicates the complexity of the integrated signaling networks in IPF. Furthermore, the expression of the repressor GLI3 was weak in fibroblast foci, so $\mathrm{HH}$ pathway activation may be strengthened in these fibrotic areas. Fitch et $\mathrm{al}^{8}$ previously described the nuclear localization of GLI1 in the remodeled epithelium in patients with interstitial lung diseases such as cryptogenic organizing pneumonia and nonspecific and usual interstitial pneumonitis, which suggests that $\mathrm{HH}$ pathway activation could be a general feature of such diseases. However, a better understanding of GLI activation in the lung epithelium will be also necessary to fully comprehend $\mathrm{SHH}$ pathway function in lung fibrosis.

Finally, we observed that $\mathrm{SHH}$ protein is expressed and secreted in both normal and IPF lungs, and $\mathrm{SHH}$ protein levels in the alveolar environment (measured in BALF) were significantly higher in exacerbated IPF than in control and stable IPF. SHH expression or release could be up-regulated with acute lung remodeling and repair, which take place during disease exacerbation.

\section{Basal Activation of HH System Is Required for Basic Fibroblast Functions}

Specific pharmacologic inhibitors targeting the $\mathrm{HH}$ pathway at different levels found that a basal activity of the SMO/GLI pathway was required for HLF proliferation. Growth of both control and IPF HLFs was inhibited with CYC (direct inhibition of SMO), HPI-4 (inhibition at the primary cilium), and GANT61 (inhibition of GLI in the nucleus). Use of the same specific $\mathrm{HH}$ pathway inhibitors showed that the $\mathrm{HH}$ pathway downstream of SMO is necessary to maintain the basal myofibroblast differentiation state of both control and IPF HLFs. For instance, CYC, HPI-4, and GANT61 decreased the basal level of $\alpha$-SMA and COL-1 in control and IPF HLFs. The basal protein level of FN1 was decreased by CYC and HPI-4 in these cell types and not GANT61, which targets GLI nuclear activity. Thus, other noncanonical pathways downstream of SMO might be implicated in the regulation 
of the basal protein expression of FN1 in HLF. However, direct activation of the $\mathrm{HH}$ pathway in vitro with recombinant SHH (100 ng/mL) or SAG (SMO agonist at $5 \mu \mathrm{mol} / \mathrm{L})$ seemed insufficient to induce myofibroblastic differentiation in control and IPF fibroblasts (data not shown). Therefore, control and IPF fibroblasts show latent, tonic $\mathrm{SMO} / \mathrm{GLI}$ basal activity that is required for basic cellular functions in HLFs in vitro.

\section{TGF- $\beta 1$ Requires SMO/GLI Pathway Activity to Trigger and Sustain Myofibroblast Differentiation}

Even though TGF- $\beta 1$ induced GL/1 and GL/2, with decreased levels of PTC and GL/3 (inhibitors of the pathway), independent of SMO in vitro, canonical GLI pathway activation (with SMO activity, the primary cilium and GLI transcriptional activity) was required to induce myofibroblast differentiation in control HLFs with TGF- $\beta 1$ stimulation (see model in Figure 8). However, in IPF HLFs, SMO basal activity was not an essential prerequisite. Indeed, IPF fibroblasts were partially resistant to CYC with TGF- $\beta 1$ because CYC did not inhibit the mRNA upregulation of $\alpha$-SMA, COL- 1 , and FN1 with TGF- $\beta 1$ treatment. These results were confirmed at the protein level only for $\alpha$-SMA and FN1. Finally, both control and IPF HLFs differentiated into myofibroblasts were resistant to CYC. However, IPF fibroblasts were sensitive to HPI-4 and GANT61 with TGF- $\beta 1$-induced differentiation to the same extent as for control HLFs. These results suggest that GLI transcriptional activity was promoted from the primary cilium, independent of SMO, in IPF HLFs by an unknown mechanism. In addition, $\mathrm{HPI}-4$ inhibition of the $\mathrm{HH}$ pathway at the primary cilium partially reverted the phenotype of TGF- $\beta 1$-differentiated control and IPF HLFs. HPI-4 greatly decreased the levels of ECM proteins such as COL-1 and FN1, but the cells still displayed a myofibroblast shape, with $\alpha$-SMA-positive stress fibers. Only the inhibition of GLI activity in the nucleus with GANT61 completely reverted the differentiation of both control and IPF myofibroblasts.

Our results suggest functional $\mathrm{HH}$ pathway machinery is required for TGF- $\beta 1$ to elicit its effect on HLFs during myofibroblast differentiation in IPF. Also, GLI transcriptional activity is required for maintaining the TGF- $\beta 1-$ induced differentiation of control and IPF HLFs into myofibroblasts with TGF- $\beta 1$ in vitro. Other developmental pathways are known to modulate TGF- $\beta$-induced myofibroblast differentiation. The WNT/ $\beta$-catenin pathway is required for inducing $\alpha$-SMA, collagen, and fibronectin in MRC-5 embryonic human lung fibroblasts with TGF- $\beta$ treatment. ${ }^{29}$ This pathway can also act upstream of TGF- $\beta$ because WNT3A ligand induced myofibroblast differentiation through TGF- $\beta$ up-regulation in mouse embryonic fibroblasts. ${ }^{30}$ Furthermore, recombinant WISP1, a WNT target gene, up-regulates the expression of ECM proteins in mouse $\mathrm{NIH} 3 \mathrm{~T} 3$ cells and primary HLFs. ${ }^{26}$ However, key embryonic signaling pathways such as FGF and NOTCH can negatively modulate TGF- $\beta 1-$ induced myofibroblast differentiation: FGF-1 inhibits the effects of TGF- $\beta 1$ on normal primary $\mathrm{HLFs}^{31}$ and
$\mathrm{NOTCH} 3$ has the same effects on mouse embryonic 10T1/2 fibroblasts. ${ }^{32}$ Thus, HH/GLI activation during TGF- $\beta$-induced myofibroblast differentiation may be a necessary cogwheel within the complex signaling system around the TGF- $\beta$ pathway, with other key embryonic pathways reactivated in IPF.

Finally, our study also shows evidence for the activation of the $\mathrm{HH}$ system in the fibrotic lung. Unlike SMO inhibition, direct inhibition of GLI transcriptional activity may be a potential therapeutic target in IPF.

\section{References}

1. King TE Jr, Pardo A, Selman M: Idiopathic pulmonary fibrosis. Lancet 2011, 378:1949-1961

2. Marchand-Adam S, Plantier L, Bernuau D, Legrand A, Cohen M, Marchal J, Soler P, Leseche G, Mal H, Aubier M, Dehoux M, Crestani $B$ : Keratinocyte growth factor expression by fibroblasts in pulmonary fibrosis: poor response to interleukin-1beta. Am J Respir Cell Mol Biol 2005, 32:470-477

3. Selman M, Pardo A, Kaminski N: Idiopathic pulmonary fibrosis: aberrant recapitulation of developmental programs? PLoS Med 2008, 5:e62

4. Wilson CW, Chuang PT: Mechanism and evolution of cytosolic Hedgehog signal transduction. Development 2010, 137:2079-2094

5. Pepicelli CV, Lewis PM, McMahon AP: Sonic hedgehog regulates branching morphogenesis in the mammalian lung. Curr Biol 1998, 8:1083-1086

6. Chuang PT, Kawcak T, McMahon AP: Feedback control of mammalian Hedgehog signaling by the Hedgehog-binding protein. Hip1, modulates Fgf signaling during branching morphogenesis of the lung. Genes Dev 2003, 17:342-347

7. Wang C, Pan Y, Wang B: Suppressor of fused and Spop regulate the stability, processing and function of Gli2 and Gli3 full-length activators but not their repressors. Development 2010, 137:2001-2009

8. Fitch PM, Howie SE, Wallace WA: Oxidative damage and TGF-beta differentially induce lung epithelial cell sonic hedgehog and tenascin-C expression: implications for the regulation of lung remodelling in idiopathic interstitial lung disease. Int J Exp Pathol 2011, 92:8-17

9. Stewart GA, Hoyne GF, Ahmad SA, Jarman E, Wallace WA, Harrison DJ, Haslett C, Lamb JR, Howie SE: Expression of the developmental Sonic hedgehog (Shh) signalling pathway is up-regulated in chronic lung fibrosis and the Shh receptor patched 1 is present in circulating T lymphocytes. J Pathol 2003, 199:488-495

10. Coon DR, Roberts DJ, Loscertales M, Kradin R: Differential epithelial expression of SHH and FOXF1 in usual and nonspecific interstitial pneumonia. Exp Mol Pathol 2006, 80:119-123

11. Raghu G, Collard HR, Egan JJ, Martinez FJ, Behr J, Brown KK, Colby TV, Cordier JF, Flaherty KR, Lasky JA, Lynch DA, Ryu JH, Swigris JJ, Wells AU, Ancochea J, Bouros D, Carvalho C, Costabel U, Ebina M, Hansell DM, Johkoh T, Kim DS, King TE Jr, Kondoh Y, Myers J, Muller NL, Nicholson AG, Richeldi L, Selman M, Dudden RF, Griss BS, Protzko SL, Schunemann HJ: An official ATS/ERS/JRS/ALAT statement: idiopathic pulmonary fibrosis: evidence-based guidelines for diagnosis and management. Am J Respir Crit Care Med 2011, 183:788-824

12. Taille C, Grootenboer-Mignot S, Boursier C, Michel L, Debray MP, Fagart J, Barrientos L, Mailleux A, Cigna N, Tubach F, MarchalSomme J, Soler P, Chollet-Martin S, Crestani B: Identification of periplakin as a new target for autoreactivity in idiopathic pulmonary fibrosis. Am J Respir Crit Care Med 2011, 183:759-766

13. Collard HR, Moore BB, Flaherty KR, Brown KK, Kaner RJ, King TE Jr, Lasky JA, Loyd JE, Noth I, Olman MA, Raghu G, Roman J, Ryu JH, Zisman DA, Hunninghake GW, Colby TV, Egan JJ, Hansell DM, Johkoh T, Kaminski N, Kim DS, Kondoh Y, Lynch DA, Muller-Quernheim J, Myers JL, Nicholson AG, Selman M, Toews GB, Wells AU, Martinez FJ: Acute exacerbations of idiopathic pulmonary fibrosis. American J Respir Crit Care Med 2007, 176:636-643

14. Quesnel C, Nardelli L, Piednoir P, Lecon V, Marchal-Somme J, Lasocki S, Bouadma L, Philip I, Soler P, Crestani B, Dehoux M: Alveolar 
fibroblasts in acute lung injury: biological behaviour and clinical relevance. Eur Respir J 2010, 35:1312-1321

15. Mailleux AA, Overholtzer M, Schmelzle T, Bouillet $P$, Strasser $A$, Brugge JS: BIM regulates apoptosis during mammary ductal morphogenesis, and its absence reveals alternative cell death mechanisms. Dev Cell 2007, 12:221-234

16. Chilosi M, Poletti V, Zamo A, Lestani M, Montagna L, Piccoli P, Pedron S, Bertaso M, Scarpa A, Murer B, Cancellieri A, Maestro R, Semenzato G, Doglioni C: Aberrant Wnt/beta-catenin pathway activation in idiopathic pulmonary fibrosis. Am J Pathol 2003, 162:1495-1502

17. Plataki M, Koutsopoulos AV, Darivianaki K, Delides G, Siafakas NM, Bouros D: Expression of apoptotic and antiapoptotic markers in epithelial cells in idiopathic pulmonary fibrosis. Chest 2005, 127:266274

18. Chen JK, Taipale J, Cooper MK, Beachy PA: Inhibition of Hedgehog signaling by direct binding of cyclopamine to Smoothened. Genes Dev 2002, 16:2743-2748

19. Dennler S, Andre J, Verrecchia F, Mauviel A: Cloning of the human GLI2 promoter: transcriptional activation by transforming growth factor-beta via SMAD3/beta-catenin cooperation. J Biol Chem 2009, 284:31523-31531

20. Nolan-Stevaux O, Lau J, Truitt ML, Chu GC, Hebrok M, FernandezZapico ME, Hanahan D: GLI1 is regulated through Smoothenedindependent mechanisms in neoplastic pancreatic ducts and mediates PDAC cell survival and transformation. Genes Dev 2009, 23: 24-36

21. Hyman JM, Firestone AJ, Heine VM, Zhao Y, Ocasio CA, Han K, Sun M, Rack PG, Sinha S, Wu JJ, Solow-Cordero DE, Jiang J, Rowitch DH, Chen JK: Small-molecule inhibitors reveal multiple strategies for Hedgehog pathway blockade. Proc Natl Acad Sci U S A 2009, 106:14132-14137

22. Lauth M, Bergstrom A, Shimokawa T, Toftgard R: Inhibition of GLImediated transcription and tumor cell growth by small-molecule antagonists. Proc Natl Acad Sci U S A 2007, 104:8455-8460

23. Bellusci S, Furuta Y, Rush MG, Henderson R, Winnier G, Hogan BL: Involvement of Sonic hedgehog (Shh) in mouse embryonic lung growth and morphogenesis. Development 1997, 124:53-63
24. Chilosi M, Poletti V, Zamo A, Lestani M, Montagna L, Piccoli P, Pedron S, Bertaso M, Scarpa A, Murer B, Cancellieri A, Maestro R, Semenzato G, Doglioni C: Aberrant Wnt/beta-catenin pathway activation in idiopathic pulmonary fibrosis. Am J Pathol 2003, 162:1495-1502

25. Konigshoff M, Balsara N, Pfaff EM, Kramer M, Chrobak I, Seeger W, Eickelberg O: Functional Wnt signaling is increased in idiopathic pulmonary fibrosis. PLoS One 2008, 3:e2142

26. Konigshoff M, Kramer M, Balsara N, Wilhelm J, Amarie OV, Jahn A, Rose F, Fink L, Seeger W, Schaefer L, Gunther A, Eickelberg O: WNT1-inducible signaling protein-1 mediates pulmonary fibrosis in mice and is upregulated in humans with idiopathic pulmonary fibrosis. J Clin Invest 2009, 119:772-787

27. Kenney AM, Rowitch DH: Sonic hedgehog promotes $G(1)$ cyclin expression and sustained cell cycle progression in mammalian neuronal precursors. Mol Cell Biol 2000, 20:9055-9067

28. Regl G, Kasper M, Schnidar H, Eichberger T, Neill GW, Philpott MP, Esterbauer H, Hauser-Kronberger C, Frischauf AM, Aberger F: Activation of the BCL2 promoter in response to Hedgehog/GLI signal transduction is predominantly mediated by GLI2. Cancer Res 2004 , 64:7724-7731

29. Baarsma HA, Spanjer Al, Haitsma G, Engelbertink LH, Meurs $H$, Jonker MR, Timens W, Postma DS, Kerstjens HA, Gosens R: Activation of WNT/beta-catenin signaling in pulmonary fibroblasts by TGFbeta(1) is increased in chronic obstructive pulmonary disease. PLoS One 2011, 6:e25450

30. Carthy JM, Garmaroudi FS, Luo Z, McManus BM: Wnt3a induces myofibroblast differentiation by upregulating TGF-beta signaling through SMAD2 in a beta-catenin-dependent manner. PLoS One 2011, 6:e19809

31. Ramos C, Montano M, Becerril C, Cisneros-Lira J, Barrera L, Ruiz V, Pardo A, Selman M: Acidic fibroblast growth factor decreases alphasmooth muscle actin expression and induces apoptosis in human normal lung fibroblasts. Am J Physiol Lung Cell Mol Physiol 2006, 291:L871-L879

32. Kennard S, Liu H, Lilly B: Transforming growth factor-beta (TGF-1) down-regulates Notch3 in fibroblasts to promote smooth muscle gene expression. J Biol Chem 2008, 283:1324-1333 